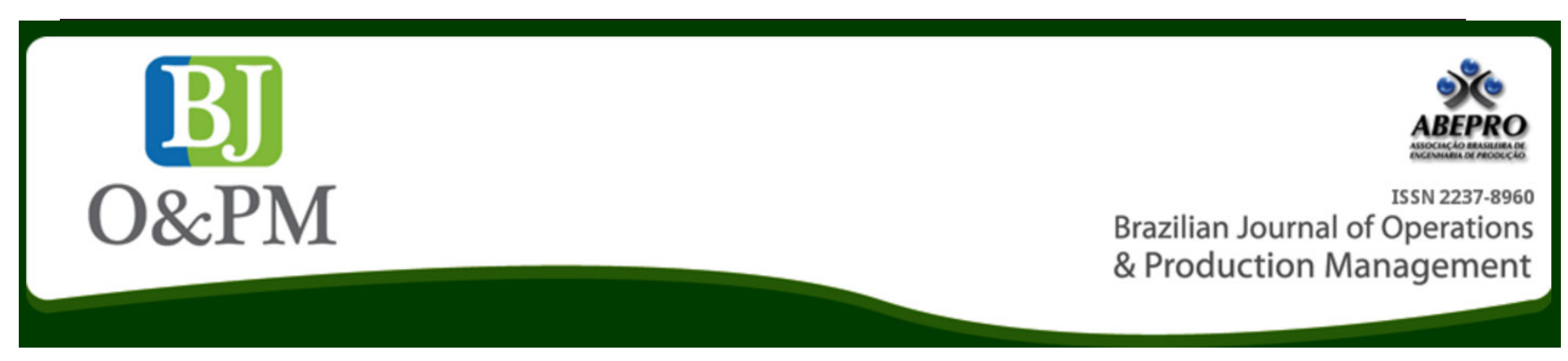

\title{
SOCIAL BEHAVIOR OF BRAZILIAN ORGANIZATIONS: AN ANALYSIS OF ISOMORPHISM MECHANISM
}

\author{
Adelaide Maria Bogo ${ }^{a}$; Alan Christian Schmitta ; Elisa Henning ${ }^{a}$; Margarete L.A. Menegotto ${ }^{b}$ \\ a Santa Catarina State University (UDESC) - Florianópolis, SC, Brazil \\ ${ }^{\mathrm{b}}$ University of Caxias do Sul (UCS) - Caxias do Sul, RS, Brazil
}

\begin{abstract}
Human's behavior is determined by variables that are commonly understood as needs and motives and, in general, it is motivated by a desire to achieve some goal. According to Maslow, these needs are constructed on a hierarchy composed of five groups - physiological, safety, love/belonging, esteem and self- actualization. In order to fulfill these needs, organizations have social behavior to address the issues of human beings, individually or collectively way. Therefore, identifying the types of actions performed and then analyzing them in the context of basic human needs, will allow us to understand isomorphic features in the social behavior of these organizations. In this sense, this study aims to analyze the social behavior of Brazilian organizations and the existence of isomorphism in these practices. The sample consists of companies listed on the ISEBOVESPA stock market and the data were collect in the Sustainability Reports. The methodology utilizes Content Analysis technique to define the categories and descriptive statistics to understand the isomorphic behavior. The findings indicate a concentration of actions on the need for 'Safety' and the existence of coercive and normative isomorphism in social activities for internal audiences and mimetic isomorphism in actions aimed at external audiences.
\end{abstract}

Keywords: Isomorphism; Human Needs; Corporate Social Responsibility; Behavior. 
Brazilian Journal of Operations \& Production Management

Volume 14, Número 1, 2017, pp. 102-111

DOI: 10.14488/BJOPM.2017.v14.n1.a11

\section{INTRODUCTION}

Brazil is a large country with social problems still to be solved (IBGE, 2013). In this context, the implementation of social actions shows its relevance as a way to alleviate some situations. In this way, organizations develop programs and social projects to contribute to minimizing social differences in Brazil, humanitarian motives are the main impulses to the adoption of social practices by organizations (Reis, 2007).

The behavior of organizations concerning the choices of social actions to be performed can originate from an institutionalized environment, which in turn can lead to the homogenization of social practices (Meyer et Rowan, 1977). Furthermore the concept that best captures the homogenization process among organizations is isomorphism, is moved forward by the pressure exerted by stakeholders and has three mechanisms: coercive, mimetic and normative (DiMaggio et Powell, 1983). The practice of isomorphism is drove by the need for organizations to survive, leading them to adapt to the environment in which they operate (Fennell, 1980; Meyer et Rowan, 1977).

The Brazilian social environment is characterized by great economic inequality between individuals, with a large portion of society living in poverty and misery (Griesse, 2007). This economic problem ends up creating social heterogeneity, a factor that leads the government, community groups and private organizations to carry out social actions in order to reduce this inequality (Griesse, 2007; Young, 2004).

Considering that human's behavior is motivated by the fulfillment of five basic needs, namely Physiological, Safety, Love/belonging, Esteem and Self-Actualization (Chiavenato, 2003; Hersey et Blanchard, 1988; Maslow, 1987), and in which organizations undertake with social actions to meet those needs, it is possible to identify in what kind of need the actions are concentrated and also the existence of institutionalized isomorphism in the environment.

Based on above, this study analyzes the social and isomorphic behavior of Brazilian organizations with regard to their social actions. By social behavior, we mean the set of actions that aim to fulfill basic human needs, which raises the following question: How has the social behavior of Brazilian organizations been performing relative to the homogenization of social practices that are meant to meet basic human needs?

This study is empirical, exploratory research with qualitative approach. The Content Analysis technique was used to categorize the groups and classify the actions (Bardin, 2014) and to make the analysis was utilized descriptive statistics. The population includes all companies listed on the ISE/BOVESPA (BOVESPA, 2014), for a total of 40 organizations. The data will be taken from the 2012 Sustainability Reports (SR). The methodological objective is to identify the social actions carried out by organizations and verify in which human needs these actions are concentrated and analyze the existence of isomorphic practices and its pressure mechanism.

We hope that this research will enable us to have a view of the isomorphism process in the social area of Brazilian organizations, see in which area of basic human needs these actions are focused and contribute to strategies for the social aspect of organizations. In addition to those contributions described above, this study will identify institutionalized behavior by organizations in the Brazilian environment that has not yet been revealed socially.

This article has seven sections. The first introduces corporate social responsibility, the second addresses isomorphism, third presents Maslow's hierarchy of needs, fourth presents the current Brazilian scenario and corporate social responsibility practiced by organizations. The fifth section explains the methodological process, data and analysis; the sixth section presents the discussion and the seventh has the conclusion.

\section{CORPORATE SOCIAL RESPONSIBILITY}

The notion that companies should be socially responsible has its origin in the idea that today we live in a world where $20 \%$ of the rich own $86 \%$ of the gross national product, a single country consumes $23 \%$ of the world's energy supply and the U.S. and Europe account for $65 \%$ of the world's wealth creation (Blowfield et Murray, 2011).

In this new conception of society a new current of thought emerges for organizations that can be synthesized in corporate social responsibility (CSR), which can be understood as a continuous process of the organization that aims to constantly monitor the environment (social, political, economic and legal) in which the organization operates and its relations with this environment (L'Etang, 1995).

CSR is based on the premise that the organization needs to behave in a socially responsible way (Asif, Searcy, Zutshi, \& Fisscher, 2013). In turn, CSR is a subset of corporate responsibility and includes the voluntary or discretionary relations of the organization with its stakeholders (Schaltegger et Wagner, 2006).

Social responsibility can be defined as the obligations of the organization and should involve four three-dimensional categories of business performance integration: economic, legal, ethical and discretionary (Carroll, 1979). On the other hand, CSR can be understood as a voluntary commitment that goes beyond the explicit and implicit obligations of conventional corporate behavior which is imposed on the organization by society's expectations (Falck et Heblich, 2007). 
CSR can also be seen as a set of 'win-win' actions in which strategy is a key factor (Falck et Heblich, 2007). It can be also seen with a clearly articulated set of policies and practices that are well communicated and reflect corporate responsibility for some of the great benefits to society (Matten et Moon, 2008).

CSR is seen by the public as a means of increasing corporate image and meeting accountability (Gray, Owen, et Maunders, 1988). With a critical view, the activity of CSR can be understood as an ideological movement to consolidate the power of organizations (Banerjee, 2008). Corporate responsibility covers economic, socio-cultural and environmental actions and social responsibility should be more than just actions and its needs to be based on values and supported by words (Ketola, 2007). Therefore, we can understand social responsibility as a set of humanistic actions aimed at meeting the needs of human beings.

Another feature that motivates organizations to practice their social responsibility may be related to organizational culture. Culture can be understood as a set of rules that guide the behavior and attitudes of most interest and meaning to people in the organization (Alvesson, 1993). It is the result of a complex process of group learning which is only partially influenced by the leader's behavior (Schein, 2004). The national culture is also a factor that interferes in the way of life of organizations where the social values and forms of cultural expression are key factors in the decisions of the organization (Hofstede, 2003).

Therefore, we can understand CSR as social behavior of the organization that is aimed at fulfilling basic human needs and which results from the social values developed based on the cultural environment in which the organization operates.

\section{ISOMORPHISM IN SOCIAL PRACTICES}

Institution, according to Burns et Scapens (2000), is a prevalent and permanent form of thought or actions which is involved in the habits of a group or the customs of a person. As such, when organizations realize that they have an institutionalized environment, they tend to homogenize their organizational practices because they understand that this mechanism allows them to increase their chances of survival (Fennell, 1980; Meyer et Rowan, 1977).

The homogenization process stems from the need to legitimize the organization (DiMaggio et Powell, 1983; Kondra et Hurst, 2009), and the concept that best captures the homogenization among organizations is called isomorphism (DiMaggio et Powell, 1983). Isomorphism is drove by the survival instincts of organizations leading them to strategic and/or operational changes (Fennell, 1980; Meyer et Rowan, 1977).
The isomorphic process among organizations happens based on three mechanisms: coercive, mimetic and normative (DiMaggio et Powell, 1983). The coercive process stems from political influence and legitimacy problems, the mimetic behavior comes from the standardization of behavior as well as responses to environmental uncertainties, and the normative mechanism comes from the professionalization of the environment (DiMaggio et Powell, 1983).

Considering that each organization operates in its own business sector and that each sector has its own set of values and assumptions and that these influence the CSR standards of this environment, organizations end up adopting the CSR structures and practices of the environment and these are perceived and appropriated by their target audience (Aerts, Cormier, \& Magnan, 2006). For these authors, the determining factors to adoption of these practices among organizations of the same environment can be institutional pressure from stakeholders, media exposure and the group to which they belong (Aerts et al., 2006). Organizations can also choose the path of control and compliance to regulatory rigor due to institutional pressures from stakeholders (Shah, 2011).

Under the competition vision, socially responsible behavior has a strong relationship with the level of competition and that organizations tend to act socially when they find a strong state of regulation, collective selfregulation in the industry, NGOs and other independent organizations to monitor the actions, as well as an institutional regulatory environment that encourages such behaviors (Campbell, 2007).

Unlike the adoption of practices, organizations can reject specific cultural practices due to external social pressure, changes in law, social values and new expectations (Kondra et Hurst, 2009).

To summarize, we can see that the business sector, society, the local community and the country itself where the organization is based, exert pressures on the organization that may compromise its survival (Meyer et Rowan, 1977). When they feel threatened, these organizations seek to adapt to the environment in which they operate in order to become competitive. Therefore, they may adopt practices already institutionalized in the environment, or they can go further and innovate in processes and products (DiMaggio et Powell 1983; Meyer et Rowan, 1977).

\section{HUMAN NEEDS}

For the theory of human relations, man's behavior is determined by variables that sometimes he himself does not understand, but those variables are understood as needs and motives (Chiavenato, 2003). For this author, these needs motivate the individual's behavior, shaping the 
Brazilian Journal of Operations \& Production Management

Volume 14, Número 1, 2017, pp. 102-111

DOI: 10.14488/BJOPM.2017.v14.n1.a11

direction and content, and are putting into three groups, namely physiological, psychological and self-realization.

Maslow (1987) complements stating that the individual is an integrated being, an organized whole and that motivation is of the individual and not of a part of him. In turn, Hersey and Blanchard (1988) state that behavior is usually motivated by a desire to achieve some goal. The individual is motivated from needs created by him, consciously or unconsciously, and that when one need is satisfied, another one emerges (Maslow, 1987).

The human's needs comprise five hierarchical groups, namely Physiological, Safety, Love/belonging, Esteem and Self-actualization (Maslow, 1987). Hartley (2010) based on Maslow presents the needs in five ordered groups according to their power, namely Physiology being first, the second is the need for Safety, the third is the need for Love and Sense of Belonging, the fourth Self-esteem and finally Selfactualization.

The Physiological needs relate to two principles, homeostasis and appetite (Maslow, 1987). These needs relate in essence to the survival of the individual and correspond to the needs for oxygen, food, sleep and rest, shelter (heat and cold) and sexual desire, among others. Safety needs include situations that give security and stability, livelihood, family and assets, threat protection and escape from danger. The Love/belonging needs include association, participation, acceptance, friendship, affection, love and family. Esteem needs are related to the way the individual is seen and evaluated and involve self-assessment, self-confidence, social approval, respect and status, among others. Finally, Self-actualization needs are related to the realization of one's own potential and continuous selfdevelopment (Chiavenato, 2003; Hartley, 2010; Maslow, 1987).

Based on this, we can analyze the social actions of organizations and check if there is any direction toward the care of the human needs, both individually and collectively. Considering that man is a being of desires and therefore ends up creating needs (Maslow, 1987), it allows us to understand that social actions of organizations, in essence, seek to meet some kind of need of the individual or the group. Some social studies that seek to find the satisfaction of the needs of individuals and the community, such as enabling people to take advantage of their own abilities are the object of as yet unresolved issues (Dover, 2011).

In short, the social actions that organizations conduct may not yet completely fulfill the needs of the human being and we should have some thoughts on the social behavior of organizations.

\section{SOCIAL REALITY IN BRAZIL}

Brazil is a country with great social inequality (Barros, Henrique et Mendonça, 2000). Even with a wealth of natural resources and potential for development, its growth has been uneven and unequal, a factor that takes part of its population into poverty (Griesse, 2007).

Based on this characteristic of social inequality, some NGOs have emerged in order to help Brazilian organizations with their social actions, including Ethos Institute, Association of Christian Business Leaders of Brazil (ADCE-Brazil), Business and Social Development Foundation (FIDES), National Thought of Business Bases (PNBE), Institutes, Foundations and Businesses Group (GIFE), Brazilian Association of Toy Manufacturers (ABRINQ), Brazilian Association of Entrepreneurs for Citizenship (CIVES), Brazilian Business Council for Sustainable Development (CEBDS), Brazilian Institute of Social and Economic Analysis (IBASE) and the Solidarity Community Council. This last group is an initiative of the federal government (Griesse, 2007).

An interesting feature about the fight against poverty in Brazil is the participation of the government, community groups and private organizations, which together can build a new model of actions (Young, 2004). There is still a lot of social inequality, problems of the quality of primary education and health care problems. These and other social factors can be seen in the document 'Summary of Social Indicators: An analysis of the living conditions of Brazilians' from the IBGE, issued in 2013, which presents a look at the country's social reality (IBGE, 2013). In this document, we see some improvement in social conditions, however, much remains to be done. Because of the multidimensionality of poverty and inequality, actions and policy implementations that improve the living conditions and well-being are necessary (IBGE, 2013).

There is a range of unresolved situations in Brazil involving access to public health, low quality of education, access to housing, populations concentrated in large cities, social inequality, violence and social exclusion that end up aggravating Brazilian social problems (Francisco, 2014).

Given the above, it is clear that social problems in Brazil remain, and that social inequality, despite being fought with government policies, still exists even with the dedication of private organizations and community groups.

\section{METHODOLOGY}

This empirical study is exploratory in nature and brings a qualitative analysis of the social actions of Brazilian organizations. We intend to identify in which human needs social actions are concentrated and from this identification, to know whether there is homogeneous behavior between organizations in order to find which isomorphic mechanism, if any, is most prevalent. 
The analysis techniques used in this study include content analysis (Bardin, 2014) and descriptive statistics. Content analysis was chosen as technical to select the mother categories and son categories, to identify the types of social actions done by Brazilian organizations and to classify these actions in the respective categories.

The use of descriptive statistics allows us to see in which human needs these actions are most concentrated. The qualitative analysis will contribute to identify isomorphism practices and relate them to coercion, mimetic and normative mechanisms (DiMaggio et Powell, 1983).

Population and Sample - The population is made up of organizations listed in the ISEBOVESPA, was select a non probabilistic sample of 37 organizations, and 3 was rejected for not having disclosed the 2012 SR, or because the organization was part of a conglomerate with other companies already included, and therefore the SR was the same (BOVESPA, 2013);

Data - The data were taken from the 2012 SR of each of the sample organizations, only considering the social aspect. We analyzed the nature of social actions disclosed in the groups Labor Practices and Decent Work (LPDW), Human Rights (HR) and Society (SO), conform descripted by GRI (GRI, 2011);

Description of the methodological process - Initially, the categories were organized as mother and son categories (Bardin, 2014). Mother categories were defined based on the GRI Technical Manual (GRI, 2011), therefore, three mother categories were created: Labor Practices and Decent Work (LPDW), Human Rights (HR) and Society (SO). Responsibility for the Product was excluded from the group because its information don't have correlation with human needs in direct way

Then, for each of the mother categories, son categories were built adopting the same structure of human needs presented by Maslow: physiological, safety, social, selfesteem and self-actualization (Maslow, 1987). The classification in each of the son categories adopted the nature of the action as a criterion;

Development - The data were recorded as follows:

a) To analyze the most prevalent isomorphic mechanism we used the results of the actions of the sector (which are reported in Table 03) were adopted as a reference;

b) To analyze the actions that fulfill human needs we considered the participation in the group (which is reported in Table 02) was considered.

Thus, Table 01 presents the industry sector and companies listed on the ISEBOVESPA that were selected for analysis. Tables 02 and 03 were developed by the authors. Table 02 shows the relative frequency of the actions by mother category and son categories. In the first column are the mother categories and their respective son categories. In the second column, the 'Situation' indicates fulfillment of the actions for son categories with answers like 'Yes / No.' The third column 'Frequency' and the fourth column 'Percentage' give the frequency compared to the company group analyzed.

Table 03 shows the participation of each business sector in social actions. Objectively, this table shows the sectors where organizations focus their actions and which sector performs the most social actions. Subjectively, it is possible to perform an interpretation of the isomorphic behavior of the organizations.

\subsection{Data Analysis}

The analysis comprises the observation of three tables, shown below. In Table 01 are the organizations analyzed are identified as well as the industry in which they are classified. Table 01 is below.

Table 1. Sectors and Organizations

\begin{tabular}{|c|c|}
\hline Sector & Organizations \\
\hline $\begin{array}{l}\text { Industrial Goods/Machines and } \\
\text { Equipment }\end{array}$ & WEG \\
\hline $\begin{array}{l}\text { Industrial Goods/Transport } \\
\text { Materials }\end{array}$ & EMBRAER \\
\hline Non-cyclic Basic/Processed Foods & BRF AS \\
\hline $\begin{array}{l}\text { Non-cyclic consuption/Prod. } \\
\text { Personal Cleansing }\end{array}$ & NATURA \\
\hline $\begin{array}{l}\text { Construction and Transport./Constr. } \\
\text { and Engineering }\end{array}$ & EVE \\
\hline $\begin{array}{l}\text { Construction and Transportation/ } \\
\text { and Transport }\end{array}$ & CCR SA; ECORODOVIAS \\
\hline Non-cyclic consuption/Health & FLEURY \\
\hline $\begin{array}{l}\text { Finance and Others/Financial } \\
\text { Intermediaries }\end{array}$ & $\begin{array}{l}\text { BICBANCO; BRADESCO; BRASIL; } \\
\text { ITAU SA; SANTANDER BR }\end{array}$ \\
\hline Finance and Others/Insurance & SULAMERICA \\
\hline $\begin{array}{l}\text { Finance and Others/Miscellaneous } \\
\text { Finance Services }\end{array}$ & CIELO \\
\hline Basic Materials/Wood and Paper & $\begin{array}{l}\text { DURATEX; FIBRIA; KLABIN S/A; } \\
\text { SUZANO PAPEL }\end{array}$ \\
\hline Basic Materials/Mining & VALE \\
\hline Basic Materials/Chemicals & BRASKEN \\
\hline Basic Materials/Metallurgy & GERDAU \\
\hline Telecom/Land-line Telephony & Ol \\
\hline Telecom/Mobile Telephony & TIM PART S/A \\
\hline Public Utilities/Water and Sanitation & COPA SA; SABESP \\
\hline Public Utilities/Electrical Energy & $\begin{array}{l}\text { AES TIETE; CEMIG; CESP; COPEL; } \\
\text { CPFLENERGIA; ELETROBRAS; } \\
\text { ELETROPAULO; ENERGIAS BR; } \\
\text { LIGHT S/A; TRACTEBEL }\end{array}$ \\
\hline
\end{tabular}

Source: (BOVESPA, 2013) compiled by the author 
Brazilian Journal of Operations \& Production Management

Volume 14, Número 1, 2017, pp. 102-111 DOI: 10.14488/BJOPM.2017.v14.n1.a11

We can see that the sectors 'Finance and Other/Financial Intermediaries' and 'Public Utilities/Electrical Energy' have the most companies listed. The following analysis refers to the social behavior of organizations and is based on Table 02 .

The analysis of Table 02 is doing by mother category and in each one is included the set of son categories followed by the analysis of the predominant isomorphic behavior.

a) Labor Practices and Decent Work (LPDW) - There is a concentration of actions for the need for 'Safety'. But for the 'Physiological' needs, no organization dedicated any attention, the same to 'Selfactualization'. However, for the 'Love/belonging' and 'Self-esteem' needs, there are investments but not as much.

For 'Safety' the programs/projects are directed toward family health and education. For 'Love/belonging' needs the focus is on social inclusion, adaptation of the individual in society after retirement and sports activities outside the company, and 'Self-esteem' actions are geared towards valuing the individual through awards.

Analyzing from the perspective of isomorphism, based on Table 03 and considering the types of actions carried out by organizations with their workforce, there is a predominance of the coercive mechanism. The normative and mimetic mechanisms are present, however, to be certain which of the two has prevalence is only possible if we enter into the decision-making process.

The most common coercive actions identified in the included analytical research on LPDW, concerning the employment relationship, involve the employment contract or civil service admission exam, internal safety activities in accordance with the workplace safety group, meetings regarding workplace safety and programs such as the emergency brigade. There are also actions regarding workplace health resulting from occupational health programs such as hearing conservation, respiratory protection programs, biosafety and ergonomics.

The most common normative actions involve training and education for employees focused on technical and professional qualifications, at the three levels of education: technical, undergraduate and graduate, either in the classroom or through distance learning. Most undergraduate and graduate programs receive financial assistance from the organization in the form of a scholarship. There are also programs aimed at internships, apprenticeships and trainee programs.

There are another programs focused on workers' health and they are usually extended to include their dependents. Most of them deal with physical and mental health, smoking, alcohol and drugs, chronic diseases, women's health, pregnancy, healthy eating, sex and visual and/or hearing impairment.

In the areas of career and employee compensation, there are also normative aspects in the behavior of the organizations. It was found that it is common practice among organizations to establish meritocracy programs to do employee promotions, usually with performance evaluation programs that link the progression and compensation to performance. Some companies use profit sharing as an additional form of compensation and in some cases link this to job performance, as is the case at the management and executive levels. It is also a common practice to establish the job and salary plan, independent of any evaluation for performance or merit.

b) Human Rights (HR) - There are actions for 'Safety' and 'Love/belonging' needs, both with $5.4 \%$. For isomorphism, based on Table 03, it was not possible to identify the predominant mechanism since the sample has a small number of actions in this social aspect.

In this mother category the actions focus on gender diversity, ethnicity, age, religion, sexual orientation and people with disabilities. There are also programs aimed at vaccination, wellness, youth entering the job market, recognition of the struggle for land and respect for indigenous peoples and traditional communities, this last one including the resettlement of land.

Table 2. Actions and Relative Frequency by Organizations

\begin{tabular}{|l|c|c|c|}
\hline \multicolumn{1}{|c|}{ ACTIONS GROUP } & SITUATION & FREQUENCY & PERCENTAGE \\
\hline LPDWPhysiological & No & 37 & 100 \\
\hline LPDWSafety & Yes & 37 & 100 \\
\hline LPDWLove/belonging & Yes & 8 & 21,6 \\
\hline LPDWEsteem & Yes & 2 & 5,4 \\
\hline LPDWSelf-actualization & No & 37 & 100 \\
\hline HRPhysiological & Yes & 1 & 2,7 \\
\hline HRSafety & yes & 2 & 5,4 \\
\hline HRLove/belonging & yes & 2 & 5,4 \\
\hline HREsteem & No & 37 & 100 \\
\hline HRSelf-actualization & No & 37 & 100 \\
\hline SOPhysiological & yes & 10 & 27 \\
\hline SOSafety & yes & 36 & 97,3 \\
\hline SOLove/belonging & yes & 21 & 56,8 \\
\hline SOEsteem & yes & 1 & 2,7 \\
\hline SOSelf-actualization & No & 37 & 100 \\
\hline LPDW - Labor Practices and Decent Work & & \\
\hline HR - Human Rights & & & \\
SO - Society & & & \\
\hline
\end{tabular}

There is coercive pressure about the treatment to indigenous people by energy industry because they need to accomplish the Convention nr. 169 about Indigenous People and Tribal (Brasil, 2004);

c) Society (SO) - There is focus on actions aimed at 'Safety', with $97.3 \%$, followed by 'Love/belonging' actions, with $56.8 \%$, then 'Physiological' actions with $27 \%$, and 'Self-esteem' with $2.7 \%$. 
In isomorphic terms, in Table 03 we see mimetic behavior between organizations. Viewed analytically, the actions may not represent mimetic behavior because this study did not do research on decision-making in the choice of actions. However, if we look at the industry's behavior as well as companies listed on the ISEBOVESPA, it appears that there is mimicry between organizations, since all focus their actions on 'Safety' and 'Love/belonging' needs. Few invest in 'Physiological' and almost none invests in 'Self-esteem' and 'Self-actualization'.

The actions aimed at 'Safety' involve education programs, technical courses for young people, participation in social programs like apprenticeships, digital inclusion, entrepreneurship, sports, arts, theater, volunteering, and training to underprivileged communities. Blood donations, support for adolescents and children with cancer, environmental education, supporting social organizations, technical cooperation, financial education, undergraduate and graduate scholarships, accessibility, support/donations to youth councils, support for projects and reintegration into society.

For 'Love/belonging' needs, the actions are addressed towards the arts, cinema, theater, traditional festivals, music, cultural events, restoration work, citizenship, volunteering, cycling, sports competitions, contests with prizes and social gatherings.

Actions to meet 'Physiological' needs mostly include food donations to social organizations, pediatric cancer care programs, infant feeding, vaccination, blood donation and examination campaigns, Christmas campaigns, emergency programs, pediatric and family health and cooperative actions.

Table 03 has a breakdown, by sector, of action groups in which organizations carry out their social responsibility.

Table 03 identifies the social behavior of the sectors. Analyzing vertically, we can see that the 'Safety' item receives the most attention from the organizations, where in LPDW $100 \%$ of the sectors have actions and in 'Society' $94 \%$ of the sectors have actions. The other need worth mentioning is the 'Physiological' which of the total to $53 \%$ of sectors investing in this need.

Analyzing this table horizontally, it appears that the sectors with the greatest diversity of actions in the SO mother category are 'Non-Cyclic consumption/ Products Personal Cleaning' and 'Finance and Others/Financial Intermediaries' with a concentration in 'Safety,' 'Love/Belonging' and 'Selfesteem' in LPDW and SO. The sectors 'Telecommunications/

Table 3. Participation in Social Actions by Sector

\begin{tabular}{|c|c|c|c|c|c|c|c|c|c|c|c|c|c|c|c|c|c|}
\hline \multirow{2}{*}{ SECTOR } & \multicolumn{5}{|c|}{ LPDW } & \multicolumn{5}{|c|}{ HR } & \multicolumn{5}{|c|}{ so } & \multirow{2}{*}{$\mid \begin{array}{l}\text { Total } \\
\text { ações }\end{array}$} & \multirow{2}{*}{$\%$} \\
\hline & $\mathbf{P}$ & s & 1-b & $\mathrm{E}$ & S-a & $\mathbf{P}$ & $\mathrm{s}$ & I-b & \begin{tabular}{l|l}
$E$ & $S$
\end{tabular} & S-a & $\mathbf{P}$ & $\mathrm{s}$ & $\mid-b$ & E & S-a & & \\
\hline $\begin{array}{l}\text { Industrial Goods/Machines and } \\
\text { Equipment }\end{array}$ & & $\mathrm{x}$ & & & & & $\mathrm{x}$ & $\mathrm{x}$ & & & & & & & & 3 & 4,3 \\
\hline Industrial Goods/Transport Materials & & $\mathbf{x}$ & & & & & & & & & & $\mathrm{x}$ & & & & 2 & 2,9 \\
\hline Non-cyclic Basic/Processed Foods & & $\mathrm{x}$ & & & & & & & & & & $\mathrm{x}$ & $x$ & & & 3 & 4,3 \\
\hline $\begin{array}{l}\text { Non-cyclic consumption/Prod. Personal } \\
\text { Cleaning }\end{array}$ & & $x$ & $x$ & $\mathrm{x}$ & & & $\mathrm{x}$ & $\mathrm{x}$ & & & & $\mathrm{x}$ & $\mathrm{x}$ & & & 7 & 10,1 \\
\hline $\begin{array}{l}\text { Construction and Transport./Constr. } \\
\text { and Engineering }\end{array}$ & & $\mathrm{x}$ & & & & & & & & & $x$ & $x$ & & & & 3 & 4,3 \\
\hline $\begin{array}{l}\text { Construction and } \\
\text { Transportation/Transport }\end{array}$ & & $\mathrm{x}$ & & & & & & & & & & $\mathrm{x}$ & $\mathrm{x}$ & & & 3 & 4,3 \\
\hline Non-cyclic consumption/Health & & $\mathrm{x}$ & & & & & & & & & $\mathrm{x}$ & $\mathrm{x}$ & $\mathrm{x}$ & & & 4 & 5,8 \\
\hline $\begin{array}{l}\text { Finance and Others/Financial } \\
\text { Intermediaries }\end{array}$ & & $x$ & $\mathrm{x}$ & $\mathrm{x}$ & & & & & & & $\mathrm{x}$ & $\mathrm{x}$ & $\mathrm{x}$ & $\mathrm{x}$ & & 8 & 11,6 \\
\hline Finance and Others/Insurance & & $\mathrm{x}$ & & & & & & & & & & $\mathrm{x}$ & & & & 2 & 2,9 \\
\hline $\begin{array}{l}\text { Finance and Others/Miscellaneous } \\
\text { Financ Services }\end{array}$ & & $x$ & & & & & & & & & $\mathrm{x}$ & $\mathrm{x}$ & $\mathrm{x}$ & & & 4 & 5,8 \\
\hline Basic Materials/Wood and Paper & & $\mathrm{x}$ & & & & & & & & & $\mathrm{x}$ & $\mathrm{x}$ & $\mathrm{x}$ & & & 4 & 5,8 \\
\hline Basic Materials/Mining & & $x$ & & & & $\mathrm{x}$ & & & & & $\mathrm{x}$ & $\mathrm{x}$ & & & & 4 & 5,8 \\
\hline Basic Materials/Chemicals & & $\mathrm{x}$ & & & & & & & & & & $\mathrm{x}$ & $\mathrm{x}$ & & & 3 & 4,3 \\
\hline Basic Materials/Metallurgy & & $\mathrm{x}$ & & & & & & & & & & $\mathrm{x}$ & & & & 2 & 2,9 \\
\hline Telecom/Land-line Telephony & & $\mathrm{x}$ & $\mathrm{x}$ & & & & & & & & $\mathrm{x}$ & $\mathrm{x}$ & $\mathrm{x}$ & & & 5 & 7,2 \\
\hline Telecom/Mobile Telephony & & $\mathrm{x}$ & $\mathrm{x}$ & & & & & & & & $\mathrm{x}$ & $x$ & & & & 4 & 5,8 \\
\hline Public Utilities/Water and Sanitation & & $\mathrm{x}$ & & & & & & & & & $\mathrm{x}$ & $x$ & $\mathrm{x}$ & & & 4 & 5,8 \\
\hline Public Utilities/Electrical Energy & & $\mathrm{x}$ & $\mathrm{x}$ & & & & & & & & & $\mathrm{x}$ & $\mathrm{x}$ & & & 4 & 5,8 \\
\hline Percentage results (\%) & 0 & 100 & 29 & 12 & 0 & 6 & 12 & 12 & 0 & 0 & 53 & 94 & 65 & 6 & 0 & 69 & 100 \\
\hline $\begin{array}{l}\text { LPDW - Labor Practice and Decent } \\
\text { Work }\end{array}$ & & Physi & iolog & gical & & & & & & & eem & & & & & & \\
\hline HR - Hurman Rights & & Safet & & & & & & & S-a- & - Sel & lf-ac & ctual & lizat & tion & & & \\
\hline SO - Society & $L-1$ & - Lov & $\mathrm{e} / \mathrm{be}$ & elon & ging & & & & & & & & & & & & \\
\hline
\end{tabular}


Brazilian Journal of Operations \& Production Management

Volume 14, Número 1, 2017, pp. 102-111

DOI: 10.14488/BJOPM.2017.v14.n1.a11

Land-line Telephony' with 7,2\% is concentrated in 'Physiological', 'Safety' and 'Love/belonging'.

The 'Public Utilities/Water Sanitation' has concentrated its actions in SO and attend 'Physiological', 'Safety' and 'Love/belonging' needs. The 'Public Utility/Electrical Energy' sector has actions to meet 'Safety' and 'Love/belonging' needs and they are concentrated in the LPDW and SO categories.

In other sectors there is a concentration of actions aimed at meeting the needs of 'Safety', then 'Love/belonging' needs. They are concentrated only in the SO mother category. It was also found that all sectors except 'Industrial Goods/Machines and Equipment' have social actions aimed at 'Safety' needs.

Analyzing the isomorphic behavior of the sectors, we can see that the mimetic and coercive mechanisms are predominant. In LPDW, the coercive mechanism prevails because there are strong labor laws in the country (Costa, 2005; Brasil, 1943). In the actions aimed at SO, there is an indication that the mimetic mechanism is predominant given the strong concentration of actions for the same needs by organizations.

\section{DISCUSSION}

In order to analyze the social and isomorphic behavior of Brazilian organizations regarding the social actions carried out in view of basic human needs, the initial question that was defined was 'How has the social behavior of Brazilian organizations been presented regarding the homogenization of social practices and fulfilling basic human needs?'

The data indicate that, in terms of fulfilling human needs, the highest concentration of actions are in the 'Safety' item, then comes 'Love/belonging' item followed by 'Physiological' needs. The other part of the question regarding the homogenizing characteristics, observed in Table 03, is the coercive isomorphism in the actions geared toward the safety need in the LPDW mother category in $100 \%$ of the organizations. In the HR there is insufficient evidence to support the isomorphic mechanism as predominant, however, in the SO category there is an indication of the mimetic mechanism. The fact that there is the great concentration in the SO, how showed Table 03 with $53 \%$ of the sectors have actions in 'Physiological', 94\% in 'Safety' and 65\% in 'Love/belonging', indicate that there is a mimetic mechanism because it is related to strategic CRS decision to invest in the same actions that the sector is investing. This behavior reduces uncertainty and increase the legitimacy.

As shown in Table 03, there is a concentration of actions in 'Love/belonging' and 'Safety' and this may happen due to the social characteristics of the country which, as the IBGE shows, still has many social problems to be solved. Thus, the concentration of actions in these two needs may indicate mimetic behavior motivated by the current situation in Brazil.

We noticed that only a few sectors have actions in the 'Physiological' need, which are Transport, non-cyclical consumption, financial, basic materials, telephony/ telecommunications and water and sanitation.

Considering that one of the objectives of this work is to identify isomorphic aspects in activities of social responsibility in Brazilian organizations, it was found that isomorphism is presented in the behavior of organizations both in the activities for internal audiences and external audiences. For internal audiences, the behavior is expressed most prominently in 'Safety' activities. This characteristic may occur due to the strongly established regulatory pressure in the country. For external audiences, the behavior is expressed more intensely in the 'Safety' activities and this feature can occur due to the social reality of the country.

Of the actions aimed at 'Safety', there is a concentration in training courses, both basic and technical and also for the arts. It was interesting to see that some organizations carry out actions aimed at social needs and usually these actions are intended for employees that have already retired. Understanding the characteristics of the social behavior of organizations of a country allows us to know the country itself and how the social responsibility of organizations is institutionalized.

The concentration of activities in 'Safety' and 'Love/ belonging' needs, may reflect a maturing of organizations and society, and the fact that some actions are conducted in partnership reflect the major advance in the concept of teamwork. The findings of this research provide a new concept of to make CSR, the new way where the organizations can join effort and together to work where there is lack of social actions. It is the new way to do CSR.

\section{CONCLUSION}

Considering the goal of this research, the data collected from the Sustainability Reports allow us to assume with a relative safety margin that there is isomorphism in Brazilian organizations, particularly in the coercive and normative aspects of social activities for internal audiences. In actions aimed at external audiences targeted to meet human needs, there was a concentration of 'Safety' and 'Love/belonging' items, and this behavior may represent a practice of mimicry in the organizations.

It should be noted that due to the subjectivity in defining the actions in terms of their classification in basic human needs, we identified a difficulty to understanding whether every action stems from a normative pressure or it is a 
question of the organization opting for mimicry, given that the research did not enter into the internal processes of decision-making.

The difficulty of accurately understanding the difference between an action that meets the Physiological need or the Safety need, or between Safety and Love/belonging is a limitation of the research. Another limitation concerns the lack of standardization of reports and the existence of the same information being presented in different sections of the SR with a different approach. The difficulty in understanding the nature and its essence may be related to the multidisciplinary quality of CSR (Aguinis \& Glavas, 2012), or even a short description of the project, or a project including actions that meet more than one need.

From the evidence in this study, it can be assumed that organizations can reflect on the effectiveness of their actions if they look at society holistically. They can, based on this view, organize themselves together to effectively meet the needs of human beings. They can make intensive use of management accounting, management control, CSR strategy and, because of this, organize themselves differently than they do today, in a way that is more appropriate for transparency and comparative analyses. The dynamic process of organizing society assumes constant change and adaptation and for this reason, studies that shed light on social issues can be helpful.

We need to have the conscientiousness that is not pleasant living in an the same environment where some people are very rich and other are very poor whose physiological needs remain unfulfilled.

New researches can be developed based on this study, such as understanding why actions for Physiological needs are still done in a country like Brazil, or why organizations focus their actions on Safety. Another option for further study could be to understand the reasons for the decisions of the organizations in the choices of actions, how the accounting done in internal procedures of the CSR, how social issues are embedded in the CSR strategy or in management controls.

\section{REFERENCES}

Aerts, W., Cormier, D. et Magnan, M. (2006), "Intraindustry imitation in corporate environmental reporting: An international perspective", Journal of Accounting and Public Policy, 25, 299-331.

Aguinis, H. et Glavas, A. (2012), "What We Know and Don't Know About Corporate Social Responsibility: A Review and Research", Agenda Journal of Management, 38(4), 932968.

Alvesson, M. (1993), Cultural Perspectives on Organizations. New York: Cambridge University Press.
Asif, M., Searcy, C., Zutshi, A. et Fisscher, O. A. M. (2013), "An integrated management systems approach to corporate social responsibility", Journal of Cleaner Production, 56, 7-17.

Banerjee, S. B. (2008), "Corporate Social Responsibility: The Good, the Bad and the Ugly", Critical Sociology, 34(1), 51-79.

Bardin, L. (2014). Análise de Conteúdo. Lisboa: Edições 70.

Barros, R. P., Henrique, R. et Mendonça, R. (2000), "Desigualdade e Pobreza no Brasil: retrato de uma estabilidade inaceitável", Revista Brasileira de Ciências Sociais, 15(42), 123-142.

BOVESPA (2013), ISE - Indice de Sustentabilidade Empresarial, 2013, available in: <https://www.isebvmf.com. br/index.php?r=site/conteudo\&id=1>, accessed: 15 nov.

BOVESPA (2014), Índice de Sustentabilidade Empresarial - ISE, from BM\&FBOVESPA, available in: <http://www. bmfbovespa.com.br/indices/Resumolndice.aspx?!ndice=ISE \&Opcao $=0$ \&idioma $=$ pt-br>

Brasil (1943), Consolidação das Leis do Trabalho. Governo Federal. Decreto Lei 5452, de 01/05/1943.

Burns, J. et Scapens, R. W. (2000), "Conceptualizing management accounting change: an institutional framework", Management Accounting Research, 11, 3-25.

Campbell, J. L. (2007), "Why Would Corporations Behave in Socially Responsible Ways? An Institutional Theory of Corporate Social Responsibility", Academy of Management Review, 32(3), 946-967.

Carroll, A. B. (1979), "A Three-Dimensional Conceptual Model of Corporate Performance", Academy of Management Review, 4(4), 497-505.

Chiavenato, I. (2003), "Teoria Geral da Administração: uma visão agrangente da moderna administração das organizações", 7a. ed., Rio de Janeiro: Editora Campus.

Costa, M. da S. (2005), "O Sistema de Relações de Trabalho no Brasil: alguns traços históricos e sua precarização atual", Revista Brasileira de Ciências Sociais, 20(59), 111-170.

Dimaggio, P. J. et Powell, W. W. (1983), "The Iron Cage Revisited: Institutional Isomorphism and Collective Rationality in Organizational Fields", American Sociological Review, 48(2), 147-160.

Dover, M. A. (2011), Human Needs. Cleveland: Oxford.

E Francisco, W. C. (2014), "Problemas sociais nas cidades do Brasil", Retrieved from http://www.mundoeducacao. com/autor/wagner-de-cerqueira-e-francisco

Falck, O. et Heblich, S. (2007), "Corporate social responsibility: Doing well by doing good", Business Horizons, $50,247-254$. 
Fennell, M. L. (1980) "The Effects of Environmental Characteristics on the Structure of Hospital Clusters", Administrative Science Quarterly, 25(3), 485-510.

Gray, R., Owen, D. et Maunders, K. (1988), “Corporate Social Reporting: Emerging Trends in Accountability and the Social Contract", Accounting, Auditing and Accountability, 1(1), 6-20.

GRI (2011), TP - Technical Protocol - Applying the Report Content Principles: Global Reporting Initiative.

Griesse, M. A. (2007), "The Geographic, Political, and Economic Context for Corporate Social Responsibility in Brazil". Journal of Business Ethics, 73(1), 21-37.

Hartley, D. (2010), Understanding Human Need: Social Issues, Policy and Practice. Bristol: Policy Press.

Hersey, P. et Blanchard, K. (1988), Management of Organizational Behavior (5th ed.). Englewood Cliffs (New Jersey): Prentice-Hall.

Hofstede, G. (2003), Culturas e Organizações compreender a nossa programação mental (A. Fidalgo, Trans. 1a. ed - 2a. reimp. ed.): Edições Sílabo.

IBGE (2013), Síntese de Indicadores Sociais: uma análise das condições de vida dos brasileiros. Rio de Janeiro: Instituo Brasileiro de Geografia e Estatística.

Kondra, A. Z. et Hurst, D. C. (2009), "Institutional processes of organizational culture". Culture and Organization, 15(1), 39-58.

L'Etang, J. (1995), "Ethical Corporate Social Responsibility: A Framework for Managers", Journal of Business Ethics, 14, 125-132.

Maslow, A. H. (1987), Motivation and Personality (3th Ed.). New York: Harper \& Row.

Matten, D. et Moon, J. (2008), "“Implicit" and "Explicit" CSR: A Conceptual Framework for A Comparative Understanding of Corporate Social Responsibility". Academy of Management Review, 33(2), 404-424.

Meyer, J. W. et Rowan, B. (1977), "Institutionalized Organizations: Formal Structure as Myth and Ceremony." American Journal of Sociology, 83(2), 340-363. Retrieved from http://www.jstor.org/stable/2778293 website:

Reis, C. N. (2007), "A Responsabilidade Social das Empresas: o contexto brasileiro em face da ação consciente ou do modernismo do mercado?", Revista de Economia Contemporanea, 11(2), 279-305.

Schaltegger, S. et Wagner, M. (2006), “Managing sustainability performance measurement and reporting in an integrated manner - Sustainability accounting as the link between the Sustainability Balanced Scorecard and sustainability reporting", Eco-Efficiency in Industry and Science (Vol. 21, pp. 681-697).

Schein, E. H. (2004), Organizational Culture and Leadership (3rd ed.). San Francisco: Jossey-Bass.

Shah, K. U. (2011), "Strategic organizational drivers of corporate environmental responsibility in the Caribbean hotel industry" Policy Sci, 44, 321-344.

Young, R. (2004), "Dilemmas and advances in corporate social responsibility in Brazil: The work of the Ethos Institute". Natural Resources Forum, 28(4), 291-301. 